\title{
PENGUKURAN DAYA SAING KABUPATEN LAMPUNG TENGAH: METODE LOCATION QUOTIENT DAN SHIFT-SHARE ANALYSIS
}

\author{
CENTRAL LAMPUNG REGENCY COMPETITIVENESS \\ MEASUREMENT: LOCATION QUOTIENT AND SHIFT-SHARE \\ ANALYSIS
}

\author{
Yanuar Pribadi ${ }^{1}$, Nurbiyanto ${ }^{2}$ \\ ${ }^{1,2}$ Politeknik Keuangan Negara STAN; \\ Email: ${ }^{1}$ yanuar.pribadi@pknstan.ac.id, ${ }^{2}$ nurbiyanto@pknstan.ac.id
}

Dikirim 22 September 2021, Direvisi 12 Oktober 2021, Disetujui 29 November 2021

\begin{abstract}
Abstrak: Penelitian ini dilakukan untuk mengidentifikasi sektor ekonomi yang menjadi basis daya saing ekonomi Kabupaten Lampung Tengah, Provinsi Lampung. Kabupaten Lampung Tengah sebagai daerah agraris masih tergolong ke dalam kabupaten dengan kemampuan keuangan daerah yang sangat kurang dan kapasitas fiskal yang rendah. Analisis kuantitatif deskriptif melalui sumber data sekunder yang berasal dari publikasi data Badan Pusat Statistik Kabupaten dan Provinsi dilakukan dengan metode Location Quotient dan Analisis Shift-share. Hasil penelitian menunjukkan bahwa hanya terdapat tiga sektor yang menjadi basis ekonomi berdasarkan metode LQ dan DLQ pada perekonomian Kabupaten Lampung Tengah yaitu Pertanian, Kehutanan dan Perikanan, Konstruksi, serta Industri Pengolahan. Analisis shift-share menghasilkan kesimpulan bahwa hanya dua sektor ekonomi pada Kabupaten Lampung Tengah yang tumbuh secara cepat dan memiliki daya saing pada periode 2016-2020 yaitu Transportasi dan Pergudangan serta Informasi dan Komunikasi. Hasil penelitian dapat digunakan sebagai masukan bagi pemangku kebijakan untuk merumuskan strategi pengembangan ekonomi Kabupaten Lampung Tengah untuk meningkatkan perekonomian daerah.
\end{abstract}

Kata kunci: Daya Saing, Location Qoutient, Pertumbuhan Ekonomi Regional, Analisis Shift-share, Sektor Basis.

Abstract: This study aims to identify the leading sector economy and competitiveness of Central Lampung Regency, Lampung Province. The regency as an agricultural area is still classified as having very poor regional financial and fiscal capacity. Descriptive quantitative analysis using the Location Quotient and Shift-share Analysis methods were used to identify the basis of the economic sector and regional competitiveness. The results showed that there were only three leading economic sectors based on the LQ and DLQ methods in the economy of Central Lampung Regency, from Agriculture, Forestry and Fisheries, Construction and Manufacturing Industries. The shift-share analysis concludes that only two economic sectors in Central Lampung Regency are growing rapidly and have competitiveness in the 2016-2020 period, namely Transportation and Warehousing and Information and Communication. The results of the study could become an input for policymakers in designing economic development strategies for Central Lampung Regency to improve the regional economy.

Keywords: Base Economic Sector, Competitiveness, Location Qoutient, Regional Economic Growth, Shift-Share Analysis.

\section{PENDAHULUAN}

Keberhasilan pembangunan ekonomi negara-negara berkembang umumnya dinilai berdasarkan pertumbuhan ekonomi negara tersebut. Pertumbuhan ekonomi yang positif menandakan bahwa kegiatan perekonomian mengalami peningkatan. Pertumbuhan ini akan bermuara pada peningkatan kesejahteraan masyarakat (Sukirno, 2000). Pada lingkup daerah, pengelolaan ekonomi daerah berada pada kewenangan pemerintah daerah sejalan dengan prinsip desentralisasi ekonomi dan fiskal.

Peningkatan kesejahteraan ekonomi masyarakat di suatu daerah akan meningkatkan tingkat daya saing masyarakat baik pada level lokal maupun nasional secara keseluruhan. Dalam rangka mencapai tingkat daya saing ini, maka pemerintah daerah perlu mengevaluasi kondisi ekonomi di daerah tersebut. Setelah evaluasi dilakukan, pemerintah daerah 
dapat menetapkan kebijakan yang tepat untuk mengembangkan sektor-sektor ekonomi yang potensial. Dengan demikian, kebijakan yang diambil merupakan kebijakan yang tepat sasaran untuk menyelesaikan akar permasalahan yang muncul.

Indikator kesejahteraan masyarakat yang juga sering digunakan ialah angka kemiskinan dan tingkat ketimpangan yang diukur melalui rasio gini. Semakin tinggi angka rasio gini, maka ketimpangan yang terjadi di masyarakat semakin besar. Pada awal tahun 2020, Provinsi Lampung berada pada urutan 11 dari 34 provinsi dengan rasio gini terkecil dengan angka sebesar 0,327 (BPS, 2020). Pada akhir tahun 2020, angka ketimpangan Provinsi Lampung semakin menurun pada angka 0,320 (BPS Lampung, 2021). Sementara itu angka kemiskinan tercatat sebanyak 1,05 juta orang atau sekitar 12,76 persen. Pada tahun 2020, Produk Domestik Regional Bruto (PDRB) Provinsi Lampung berada pada peringkat 11 dari 34 provinsi yaitu menyumbang 2,25 persen dari total Produk Domestik Bruto (PDB) Nasional.

Kabupaten Lampung Tengah merupakan salah satu daerah kabupaten di provinsi Lampung yang bercirikan agraris. Pada tahun 2020, APBD Kabupaten Lampung Tengah hampir mencapai 5 triliun rupiah. Jumlah angka kemiskinan Kabupaten Lampung Tengah sebesar 11,82 persen atau lebih kecil dari angka kemiskinan Provinsi Lampung. Namun demikian, kontribusi Kabupaten Lampung Tengah terhadap PDRB Provinsi Lampung masih rendah. Dari data Badan Pusat Statistik daerah, kontribusi PDRB Kabupaten Lampung Tengah terhadap PDRB Provinsi Lampung rata-rata per tahunnya kurang dari 1 persen (BPS Lampung, 2021). Ini menunjukkan bahwa tingkat daya saing Kabupaten Lampung Tengah sangat rendah dibandingkan daerah lain, bahkan untuk lingkup daerah provinsi.

Provinsi Lampung termasuk salah satu provinsi dengan tingkat sumbangan PDRB cukup besar terhadap PDB Nasional.
Namun demikian, tingkat daya saing daerah di provinsi Lampung terutama Kabupaten Lampung Tengah masih rendah. Kemampuan keuangan daerah yang menunjukkan kemandirian ekonomi Kabupaten Lampung Tengah juga masih berada dalam kategori sangat kurang (Afif \& Ciptawaty, 2020). Oleh karena itu, perlu dilakukan identifikasi dan penilaian sektor ekonomi yang potensial untuk dikembangkan. Setelah sektor basis ekonomi diidentifikasi, maka pemerintah daerah selaku penentu kebijakan dapat menetapkan langkah yang tepat untuk mendorong pertumbuhan ekonomi daerah sehingga bermuara pada peningkatan kesejahteraan masyarakat.

\section{LANDASAN TEORI}

\section{A. Sektor Basis Ekonomi}

Dalam lingkup ekonomi regional, pertumbuhan ekonomi di suatu daerah dapat dilihat dari perkembangan sektor ekonomi di daerah tersebut. Suatu sektor dapat dikategorikan sebagai basis ekonomi ketika sektor itu mampu memenuhi kebutuhan internal daerah kemudian mengekspor sektor tersebut ke luar daerah penghasil. Sebaliknya ada sektor nonbasis yaitu sektor yang hanya mampu memenuhi kebutuhan barang dan jasa di dalam suatu daerah. Kontribusi sektor basis terhadap perekonomian suatu daerah membuat sektor basis ini sering disebut sebagai sektor unggulan. Basis ekonomi regional dapat digunakan untuk menilai aktivitas ekspor daerah, sehingga berfungsi untuk memproyeksikan pertumbuhan tersebut dan pengaruhnya terhadap sektor-sektor yang lain (Soepono, 2001).

Sektor basis memiliki peranan sebagai penggerak utama (primer mover) dalam pertumbuhan suatu daerah. Semakin besar ekspor atau suplai ekonomi dari suatu daerah ke daerah lain, maka akan semakin maju pertumbuhan daerah tersebut (Ridwan, 2016). Peran sektor basis ini juga akan berpengaruh pada sektor nonbasis untuk berkembang menjadi sektor basis 
berikutnya. Dengan kata lain, sektor basis ekonomi dapat berfungsi memberikan efek multiplier bagi sektor nonbasis dalam perekonomian suatu daerah.

\section{B.Location Quotient dan Dynamic Location Quotient}

Dalam menentukan basis ekonomi suatu daerah, pendekatan yang umum digunakan ialah metode Location Quotient (LQ). Analisis LQ digunakan untuk mengetahui kontribusi suatu daerah sebagai supplier atau importer atas suatu aktivitas atau sektor ekonomi di daerah tersebut (Schaffer, 2010). Salah satu aspek dari analisis LQ adalah sebagai salah satu indikator untuk menentukan sektor unggulan (Basuki \& Mujiraharjo, 2017), mengukur konsentrasi relatif kegiatan ekonomi dalam penetapan sektor unggulan sebagai leading sector suatu kegiatan ekonomi (R. Jumiyanti, 2018).

Metode LQ menggunakan formula sebagai berikut (Isserman, 1977):

$$
\begin{aligned}
& L Q=\frac{(X i j) /(R V j)}{(X i) /(R V)} \\
& \text { LQ = koefisien Location Quotient } \\
& \text { sektor i di kabupaten } \mathrm{j} \\
& \mathrm{Xij}=\text { PDRB sektor } \mathrm{i} \text { di kabupaten } \mathrm{j} \\
& \mathrm{Xi}=\text { PDRB sektor } \mathrm{i} \text { di level } \\
& \text { provinsi/acuan kabupaten } \mathrm{j} \\
& \mathrm{RVj}=\text { total PDRB kabupaten } \mathrm{j} \\
& \mathrm{RV}=\text { total PDRB di level } \\
& \text { provinsi/acuan kabupaten } \mathrm{j}
\end{aligned}
$$

Hasil penghitungan nilai LQ yang lebih besar dari 1 menunjukkan bahwa laju pertumbuhan sektor amatan di suatu daerah kabupaten lebih besar dibandingkan dengan laju pertumbuhan sektor yang sama dalam perekonomian daerah provinsi/acuan. Ini juga menunjukkan bahwa sektor tersebut menjadi sektor basis ekonomi di daerah tersebut.

Hasil penghitungan nilai LQ yang lebih kecil dari 1 menunjukkan bahwa laju pertumbuhan sektor amatan di suatu daerah kabupaten lebih lambat dibandingkan dengan laju pertumbuhan sektor yang sama dalam perekonomian daerah provinsi/acuan. Dengan kata lain, sektor tersebut bukanlah basis ekonomi di daerah tersebut.

Metode Dynamic Location Quotient (DLQ) merupakan pengembangan dari LQ dengan mengakomodasi faktor laju pertumbuhan keluaran sektor ekonomi dari waktu ke waktu (Nugroho, 2010). DLQ mengakomodasi laju pertumbuhan ekonomi suatu sektor amatan maupun perekonomian secara keseluruhan selama periode tertentu. Hasil analisis DLQ menunjukkan potensi suatu sektor untuk menjadi basis ekonomi di masa mendatang. Dengan mengombinasikan antara LQ dan DLQ, pengambil kebijakan dapat menilai peran suatu sektor ekonomi dalam perekonomian termasuk prospek sektor tersebut ke depan.

Metode DLQ menggunakan rumus:

$$
\begin{aligned}
& \mathrm{DLQ}=\frac{(1+\mathrm{gij}) /(1+\mathrm{gj})}{(1+\text { gip }) /(1+\mathrm{gp})} \\
& \text { DLQ }=\text { koefisien } D L Q \text { sektor } \mathrm{i} \text { di } \\
& \text { kabupaten } \mathrm{j} \\
& \text { gij = rata-rata pertumbuhan PDRB } \\
& \text { sektor i di kabupaten } \mathrm{j} \\
& \mathrm{gj}=\text { rata-rata pertumbuhan total } \\
& \text { PDRB di kabupaten } \mathrm{j} \\
& \text { gip }=\text { rata-rata pertumbuhan PDRB } \\
& \text { sektor i di level provinsi } p \\
& \mathrm{gp}=\text { rata-rata pertumbuhan total } \\
& \text { PDRB di level provinsi } p \\
& \mathrm{t}=\text { waktu (tahun) }
\end{aligned}
$$

Nilai DLQ yang lebih besar dari 1 menunjukkan bahwa sektor amatan di daerah tersebut potensial untuk dikembangkan atau bersifat prospektif. Sebaliknya jika nilai DLQ lebih kecil dari 1, maka sektor amatan tersebut tidak prospektif dalam menjadi sektor basis ekonomi di suatu lokasi atau daerah tertentu.

\section{Analisis Kuadran Tipologi Klassen}

Salah satu indikator untuk menentukan sektor basis ekonomi suatu wilayah adalah Tipologi Klassen. Metode ini 
mengklasifikasikan sektor ekonomi suatu daerah dengan membandingkan pertumbuhan ekonomi suatu daerah amatan dengan pertumbuhan ekonomi daerah yang menjadi acuan (Sofi, 2020). Jika analisis pertumbuhan ekonomi dilakukan terhadap suatu kabupaten/kota, maka data ekonomi daerah provinsi dapat digunakan sebagai pembanding. Hasil analisis Tipologi Klassen dapat menggambarkan posisi pertumbuhan dan pangsa sektor, subsektor, usaha, atau komoditi pembentuk variabel regional suatu daerah (Kurniati, 2020).

Kombinasi antara nilai LQ dan DLQ digunakan sebagai dasar untuk mengelompokkan masing-masing aktivitas ekonomi ke dalam bagan Tipologi Klassen. Bagan tipologi Klassen memuat empat kuadran proyeksi sektor ekonomi berdasarkan nilai penghitungan LQ dan DLQ.

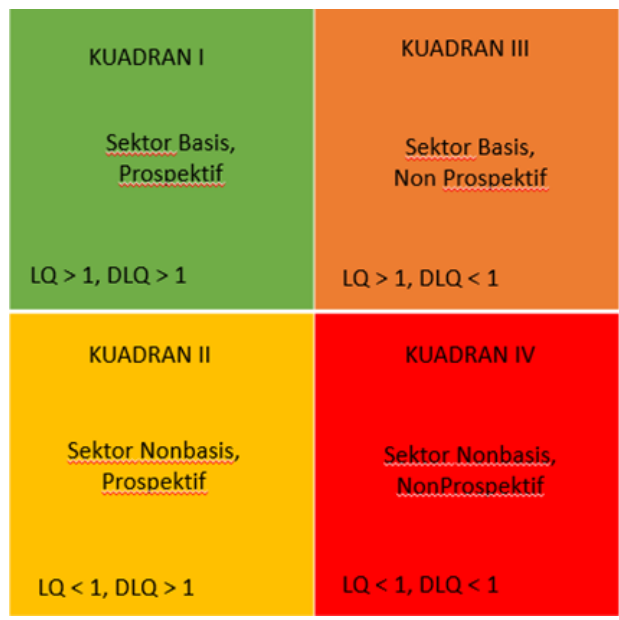

Gambar 1. Bagan Tipologi Klassen

\section{Analisis Shift-share}

Kinerja dan pertumbuhan ekonomi suatu daerah memiliki beberapa dimensi pengukuran. Salah satu alat untuk mengukur produktivitas daerah ialah metode analisis Shift-share (Arsyad, 1999). Analisis Shift-share digunakan untuk membagi pertumbuhan ekonomi suatu daerah ke dalam tiga komponen dan mengukur kontribusi dari masing-masing komponen tersebut (Curtis, 1972). Pada dasarnya analisis Shift-share merupakan analisis untuk membandingkan laju pertumbuhan ekonomi suatu lokasi/daerah dengan lingkup lokasi/daerah yang lebih luas. Shift-share suatu daerah kabupaten/kota dapat diketahui dengan membandingkan laju pertumbuhan ekonomi suatu kabupaten/kota dengan laju pertumbuhan ekonomi provinsi.

Komponen dalam melakukan analisis Shift-share antara lain pertumbuhan provinsi (PN) di suatu daerah amatan yang dapat dilihat dari perubahan produksi daerah yang disebabkan perubahan produksi daerah referensi dengan asumsi tidak ada perbedaan karakteristik ekonomi antarsektor dan antarwilayah. Kemudian ada pertumbuhan proporsional (PP) yang diukur dari pertumbuhan suatu aktivitas ekonomi daerah pada periode tertentu (Page \& Patton, 1991). Selain itu ada pertumbuhan pangsa wilayah (PPW) yang diukur dari laju pertumbuhan ekonomi suatu wilayah dibandingkan dengan wilayah lainnya. Pertumbuhan suatu sektor ekonomi daerah tertentu dapat dilihat dengan melihat pergeseran bersih (net shift) suatu sektor di daerah tersebut. Nilai pergeseran bersih (PB) ini diperoleh dari penjumlahan antara komponen $\mathrm{PP}$ dan PPW.

Rumus perhitungan analisis Shift-share:

$$
\begin{aligned}
& \mathrm{Ra}=\frac{\Delta \mathrm{Yp}^{\prime}-\Delta \mathrm{Yp}}{\Delta \mathrm{Yp}} \\
& \mathrm{Ri}=\frac{\text { Yip }^{\prime}-\text { Yip }}{\text { Yip }} \\
& r i j=\frac{Y_{i j}^{\prime}-Y i j}{Y i j} \\
& \mathrm{PNij}=\mathrm{Ra} \times \mathrm{Yij} \\
& P P i j=(R i-R a) \times Y i j \\
& P P W i j=(r i j-R i) \times Y i j \\
& P B i j=P P i j+P P W i j
\end{aligned}
$$


Keterangan:

\begin{tabular}{|c|c|c|}
\hline Ra & $=$ & Rasio PDRB di provinsi $p$ \\
\hline$\Delta \mathrm{Yp}$ & $=$ & $\begin{array}{l}\text { Total PDRB propinsi p pada } \\
\text { tahun akhir pengamatan }\end{array}$ \\
\hline$\Delta \mathrm{Yp}$ & $=$ & $\begin{array}{l}\text { Total PDRB propinsi } \mathrm{p} \text { pada } \\
\text { tahun dasar pengamatan }\end{array}$ \\
\hline $\mathrm{Ri}$ & $=$ & $\begin{array}{l}\text { Rasio PDRB sektor i di } \\
\text { Provinsi } p\end{array}$ \\
\hline Yip' & $=$ & $\begin{array}{l}\text { Sektor ekonomi i di provinsi } \\
\text { p pada tahun akhir penga- } \\
\text { matan }\end{array}$ \\
\hline Yip & $=$ & $\begin{array}{l}\text { Sektor ekonomi i di provinsi } \\
\text { p pada tahun dasar penga- } \\
\text { matan }\end{array}$ \\
\hline rij & $=$ & $\begin{array}{l}\text { Rasio PDRB dari sektor i di } \\
\text { Kabupaten } \mathrm{j}\end{array}$ \\
\hline Yij' & $=$ & $\begin{array}{l}\text { Sektor ekonomi i di } \\
\text { kabupaten j pada tahun akhir } \\
\text { pengamatan }\end{array}$ \\
\hline Yij & $=$ & $\begin{array}{l}\text { Sektor ekonomi i di kabu- } \\
\text { paten j pada tahun dasar } \\
\text { pengamatan }\end{array}$ \\
\hline PNij & $=$ & $\begin{array}{l}\text { Pertumbuhan ekonomi dari } \\
\text { provinsi pada sektor i di } \\
\text { Kabupaten } \mathrm{j}\end{array}$ \\
\hline PPij & $=$ & $\begin{array}{l}\text { Pertumbuhan proporsional } \\
\text { sektor i di kabupaten } \mathrm{j}\end{array}$ \\
\hline PPWij & $=$ & $\begin{array}{l}\text { Pertumbuhan pangsa wila- } \\
\text { yah sektor i di kabupaten } j\end{array}$ \\
\hline PBij & $=$ & $\begin{array}{l}\text { Pergeseran bersih sektor } \mathrm{i} \text { di } \\
\text { kabupaten } \mathrm{j}\end{array}$ \\
\hline
\end{tabular}

Nilai PB yang lebih besar dari 0 atau positif, menunjukkan bahwa pertumbuhan suatu sektor di daerah tertentu termasuk ke dalam kelompok progresif. Sebaliknya apabila nilai PB lebih kecil dari 0 atau negatif, maka pertumbuhan sektor tertentu di daerah tersebut termasuk ke dalam kelompok lambat. Hasil analisis Shift-share digunakan untuk mengklasifikasikan sektor dengan pertumbuhan dan daya saing dengan pengelompokan seperti pada gambar 2 .

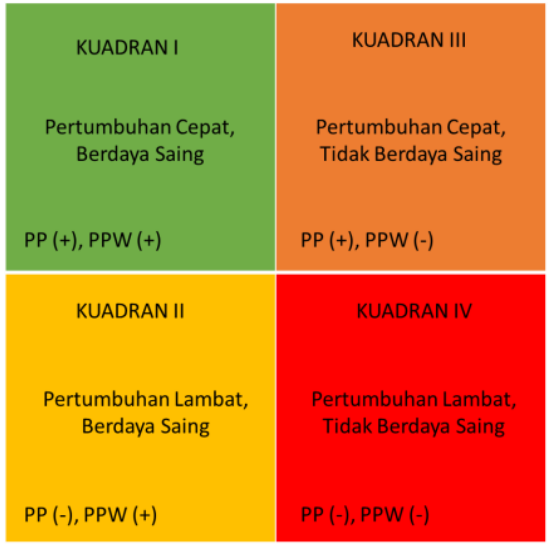

Gambar 2. Kuadran Shift-share

Sektor basis ekonomi cukup menarik untuk diteliti dalam menentukan potensi ekonomi pada suatu daerah. Penelitian untuk menganalisis sektor unggulan antara lain dilakukan di Kabupaten Sleman (Basuki \& Mujiraharjo, 2017), Kota Medan (Sihombing, 2018) dan Kabupaten Penajam Paser Utara (Sofi, 2020). Pendekatan LQ dan DLQ memang dapat menunjukkan sektor basis dari suatu daerah namun pengukuran yang lebih spesifik menggunakan pengembangan lebih lanjut dari metode Shift-share dapat memberikan gambaran yang lebih komprehensif (Arcelus, 1984), misalnya menggunakan pendekatan rasio ekspor bersih (Chiang, 2012). Tingkat daya saing suatu daerah juga dapat ditentukan melalui hasil analisis Shift-share (Khusaini, 2015) sehingga dapat diidentifikasi daerah yang menjadi eksportir dan importir sektor unggulan pada perekonomian di suatu wilayah (Oyewole, 2016).

\section{METODOLOGI}

Penelitian ini menggunakan metode deskriptif kuantitatif dengan menggunakan data sekunder berupa data PDRB yang berasal dari publikasi Badan Pusat Statistik Provinsi Lampung dan Kabupaten Lampung Tengah tahun 2016-2020. Penelitian kuantitatif merupakan penelitian yang menggunakan data berupa angkaangka numerik maupun data statistik (Sugiyono, 2011). Analisis data sekunder 
dilakukan terhadap data PDRB Kabupaten Lampung Tengah seri 2010 Atas Dasar Harga Konstan (ADHK) antara tahun 2016 s.d. 2020 dan PDRB Provinsi Lampung seri 2010 ADHK antara tahun 2016 s.d. 2020.

PDRB ADHK digunakan karena mampu menggambarkan perkembangan agregat dari tahun ke tahun menggunakan harga tetap. Hal ini menyebabkan perkembangan tersebut hanya dipengaruhi oleh perkembangan produksi riil, bukan karena inflasi atau perubahan harga. Pertumbuhan PDRB ADHK juga dapat menunjukkan laju pertumbuhan ekonomi secara keseluruhan atau setiap sektor dari tahun ke tahun.

Hasil analisis LQ dan DLQ digunakan untuk menentukan sektor basis ekonomi atau unggulan Kabupaten Lampung Tengah. Hasil analisis LQ dan DLQ tersebut digunakan sebagai dasar pengelompokan sektor basis sesuai tipologi Klassen dan selanjutnya dilakukan analisis Shift-share untuk menentukan kinerja pertumbuhan daerah kabupaten Lampung Tengah. Rerangka konsep penelitian ini dapat dilihat pada gambar 3.

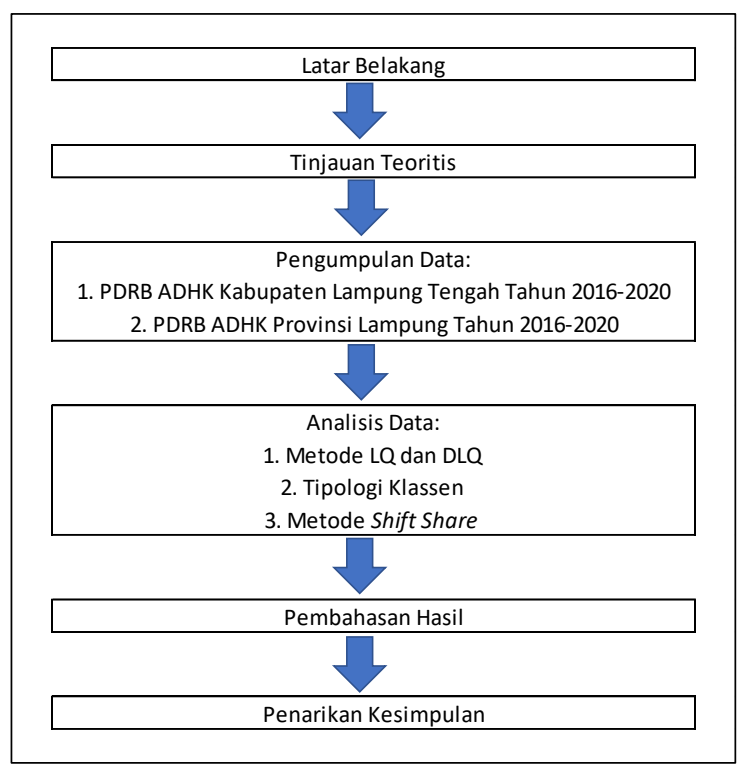

Gambar 3. Rerangka Konsep Penelitian

\section{HASIL DAN PEMBAHASAN}

\section{A. Perkembangan dan Perhitungan PDRB Kabupaten Lampung Tengah dan Provinsi Lampung Tahun 2016- 2020 Menggunakan Pendekatan Location Quotient dan Dynamic Location Quotient}

Data yang digunakan dalam penelitian ini adalah data sekunder yang dihimpun berupa PDRB Atas Dasar Harga Konstan seri 2010 antara tahun 2016-2020 Kabupaten Lampung Tengah, dan PDRB Atas Dasar Harga Konstan seri 2010 antara tahun 2016-2020 Provinsi Lampung. Data sekunder tersebut menunjukkan bahwa jumlah PDRB Kabupaten Lampung Tengah sangat kecil jika disandingkan dengan total kumulatif Provinsi Lampung. Hal ini sangat memprihatinkan karena menunjukkan bahwa perekonomian di Kabupaten Lampung Tengah tertinggal dibandingkan kabupaten/kota lain di Provinsi Lampung. Data PDRB Kabupaten Lampung Tengah dan PDRB Provinsi Lampung tahun 20162020 ditunjukkan pada Lampiran 1 dan Lampiran 2.

Data PDRB Kabupaten Lampung Tengah dan Provinsi Lampung yang sudah dikompilasikan seperti pada Lampiran 1 dan Lampiran 2 kemudian dihitung menggunakan formula LQ dan DLQ. Berdasarkan perhitungan menggunakan formula LQ dan DLQ, dapat diidentifikasi sektor ekonomi di Kabupaten Lampung Tengah yang termasuk kategori sektor basis dan nonbasis ekonomi.

Kabupaten Lampung Tengah hanya memiliki 3 sektor yang menjadi basis ekonomi dan sisanya sebanyak 14 sektor merupakan sektor nonbasis. Sektor basis tersebut antara lain Sektor Pertanian, Kehutanan dan Perikanan, Sektor Industri Pengolahan, dan Sektor Konstruksi. Hal ini menggambarkan Kabupaten Lampung Tengah tidak memiliki banyak pilihan sektor basis ekonomi untuk dijadikan fokus pembangunan ekonomi. 
Berdasarkan hasil penghitungan formula LQ dan DLQ, data sektor ekonomi Kabupaten Lampung Tengah dibandingkan dengan Provinsi Lampung dapat dilihat pada Tabel 1.

Tabel 1. Hasil Perhitungan Rata-Rata LQ Kabupaten Lampung Tengah dan Provinsi Lampung Tahun 2016-2020

\begin{tabular}{|c|c|c|c|c|}
\hline No & Sektor Ekonomi & $\begin{array}{c}\text { Rata2 } \\
\text { LQ }\end{array}$ & DLQ & $\begin{array}{l}\text { Basis/Non- } \\
\text { Basis }\end{array}$ \\
\hline 1 & $\begin{array}{l}\text { Pertanian, } \\
\text { Kehutanan, dan } \\
\text { Perikanan }\end{array}$ & 1.19 & 1.08 & Basis \\
\hline 2 & $\begin{array}{l}\text { Pertambangan dan } \\
\text { Penggalian }\end{array}$ & 0.79 & 1.15 & Non Basis \\
\hline 3 & $\begin{array}{l}\text { Industri } \\
\text { Pengolahan }\end{array}$ & 1.24 & 0.98 & Basis \\
\hline 4 & $\begin{array}{l}\text { Electricity and } \\
\text { Gas }\end{array}$ & 0.68 & 0.94 & Non Basis \\
\hline 5 & $\begin{array}{l}\text { Pengadaan Air, } \\
\text { Pengelolaan } \\
\text { Sampah dan } \\
\text { Lainnya }\end{array}$ & 0.36 & 0.94 & Non Basis \\
\hline 6 & Konstruksi & 1.14 & 1.01 & Basis \\
\hline 7 & $\begin{array}{l}\text { Perdagangan } \\
\text { Besar dan } \\
\text { Reparasi } \\
\text { Kendaraan }\end{array}$ & 0.88 & 0.98 & Non Basis \\
\hline 8 & $\begin{array}{l}\text { Transportasi dan } \\
\text { Pergudangan } \\
\text { Penyediaan }\end{array}$ & 0.53 & 1.02 & Non Basis \\
\hline 9 & $\begin{array}{l}\text { Akomodasi dan } \\
\text { Makan Minum }\end{array}$ & 0.70 & 0.96 & Non Basis \\
\hline 10 & $\begin{array}{l}\text { Informasi dan } \\
\text { Komunikasi }\end{array}$ & 0.81 & 1.03 & Non Basis \\
\hline 11 & $\begin{array}{l}\text { Jasa Keuangan } \\
\text { dan Asuransi }\end{array}$ & 0.74 & 1.02 & Non Basis \\
\hline 12 & Real Estat & 0.64 & 1.00 & Non Basis \\
\hline 13 & Jasa Perusahaan & 0.75 & 1.01 & Non Basis \\
\hline 14 & $\begin{array}{l}\text { Administrasi } \\
\text { Pemerintahan dan } \\
\text { Lainnya }\end{array}$ & 0.49 & 1.00 & Non Basis \\
\hline 15 & Jasa Pendidikan & 0.80 & 1.00 & Non Basis \\
\hline 16 & $\begin{array}{l}\text { Jasa Kesehatan } \\
\text { dan Kegiatan } \\
\text { Social }\end{array}$ & 0.54 & 1.00 & Non Basis \\
\hline 17 & Jasa Lainnya & 0.61 & 0.94 & Non Basis \\
\hline
\end{tabular}

\section{B. Analisis Sektor Basis Ekonomi Kabupaten Lampung Tengah}

Setelah diketahui nilai LQ dan DLQ, untuk menentukan sektor basis atau unggulan Kabupaten Lampung Tengah, dilakukan kompilasi kombinasi nilai LQ dan DLQ tersebut seperti pada tabel 2. Dari hasil penghitungan LQ dan DLQ, dapat diklasifikasikan sektor basis atau unggulan Kabupaten Lampung Tengah yang bersifat prospektif maupun non prospektif. Sektor yang prospektif berarti sektor tersebut memiliki kecenderungan atau potensial untuk berkembang di masa yang akan datang. Sektor basis yang prospektif maupun nonbasis yang prospektif ini dapat menjadi target pengembangan bagi pemerintah daerah sehingga pertumbuhan ekonomi di Kabupaten Lampung Tengah dapat lebih meningkat di masa mendatang. Sektor yang prospektif merupakan sektor yang berpotensi untuk mendukung tingkat pertumbuhan ekonomi jika mendapatkan perhatian dan dukungan pengembangan lebih lanjut. Dari hasil penghitungan LQ dan DLQ, kemudian diklasifikasikan ke dalam bagan tipologi Klassen untuk melihat prospek dari masing-masing sektor.

Tabel 2. Analisis LQ dan DLQ Kabupaten Lampung Tengah Tahun 2016-2020

\begin{tabular}{|c|c|c|c|c|}
\hline \multirow{2}{*}{ No } & \multirow{2}{*}{$\begin{array}{c}\text { Sektor } \\
\text { Ekonomi }\end{array}$} & \multicolumn{2}{|c|}{ INTERPRETASI } & \multirow{2}{*}{$\begin{array}{c}\text { INTER- } \\
\text { PRETASI } \\
\text { AKHIR }\end{array}$} \\
\hline & & LQ & DLQ & \\
\hline 1 & $\begin{array}{l}\text { Pertanian, } \\
\text { Kehutanan, } \\
\text { dan Perikanan }\end{array}$ & basis & prospektif & $\begin{array}{l}\text { basis, } \\
\text { prospektif }\end{array}$ \\
\hline 2 & $\begin{array}{l}\text { Pertambangan } \\
\text { dan } \\
\text { Penggalian }\end{array}$ & nonbasis & prospektif & $\begin{array}{l}\text { nonbasis, } \\
\text { prospektif }\end{array}$ \\
\hline 3 & $\begin{array}{l}\text { Industri } \\
\text { Pengolahan }\end{array}$ & basis & $\begin{array}{l}\text { non } \\
\text { prospektif }\end{array}$ & $\begin{array}{l}\text { basis, non } \\
\text { prospektif }\end{array}$ \\
\hline 4 & $\begin{array}{l}\text { Electricity } \\
\text { and Gas }\end{array}$ & nonbasis & $\begin{array}{l}\text { non } \\
\text { prospektif }\end{array}$ & $\begin{array}{l}\text { nonbasis, } \\
\text { non } \\
\text { prospektif }\end{array}$ \\
\hline 5 & $\begin{array}{l}\text { Pengadaan } \\
\text { Air, } \\
\text { Pengelolaan } \\
\text { Sampah dan } \\
\text { Lainnya }\end{array}$ & nonbasis & $\begin{array}{l}\text { non } \\
\text { prospektif }\end{array}$ & $\begin{array}{l}\text { nonbasis, } \\
\text { non } \\
\text { prospektif }\end{array}$ \\
\hline 6 & Konstruksi & basis & prospektif & $\begin{array}{l}\text { basis, } \\
\text { prospektif }\end{array}$ \\
\hline 7 & $\begin{array}{l}\text { Perdagangan } \\
\text { Besar dan } \\
\text { Reparasi } \\
\text { Kendaraan }\end{array}$ & nonbasis & $\begin{array}{l}\text { non } \\
\text { prospektif }\end{array}$ & $\begin{array}{l}\text { nonbasis, } \\
\text { non } \\
\text { prospektif }\end{array}$ \\
\hline 8 & $\begin{array}{l}\text { Transportasi } \\
\text { dan } \\
\text { Pergudangan }\end{array}$ & nonbasis & prospektif & $\begin{array}{l}\text { nonbasis, } \\
\text { prospektif }\end{array}$ \\
\hline 9 & $\begin{array}{l}\text { Penyediaan } \\
\text { Akomodasi } \\
\text { dan Makan } \\
\text { Minum }\end{array}$ & nonbasis & $\begin{array}{l}\text { non } \\
\text { prospektif }\end{array}$ & $\begin{array}{l}\text { Nonbasis, } \\
\text { non } \\
\text { prospektif }\end{array}$ \\
\hline 10 & $\begin{array}{l}\text { Informasi dan } \\
\text { Komunikasi }\end{array}$ & nonbasis & prospektif & $\begin{array}{l}\text { nonbasis, } \\
\text { prospektif }\end{array}$ \\
\hline 11 & $\begin{array}{l}\text { Jasa } \\
\text { Keuangan } \\
\text { dan Asuransi }\end{array}$ & nonbasis & prospektif & $\begin{array}{l}\text { nonbasis, } \\
\text { prospektif }\end{array}$ \\
\hline 12 & Real Estat & nonbasis & $\begin{array}{l}\text { non } \\
\text { prospektif }\end{array}$ & $\begin{array}{l}\text { nonbasis, } \\
\text { non } \\
\text { prospektif }\end{array}$ \\
\hline 13 & $\begin{array}{l}\text { Jasa } \\
\text { Perusahaan }\end{array}$ & nonbasis & prospektif & $\begin{array}{l}\text { nonbasis, } \\
\text { prospektif }\end{array}$ \\
\hline 14 & $\begin{array}{l}\text { Administrasi } \\
\text { Pemerintahan } \\
\text { dan Lainnya }\end{array}$ & nonbasis & $\begin{array}{l}\text { non } \\
\text { prospektif }\end{array}$ & $\begin{array}{l}\text { nonbasis, } \\
\text { non } \\
\text { prospektif }\end{array}$ \\
\hline
\end{tabular}




\begin{tabular}{|c|c|c|c|c|}
\hline \multirow{2}{*}{ No } & \multirow{2}{*}{$\begin{array}{c}\text { Sektor } \\
\text { Ekonomi }\end{array}$} & \multicolumn{2}{|c|}{ INTERPRETASI } & \multirow{2}{*}{$\begin{array}{c}\text { INTER- } \\
\text { PRETASI } \\
\text { AKHIR }\end{array}$} \\
\hline & & LQ & DLQ & \\
\hline 15 & $\begin{array}{l}\text { Jasa } \\
\text { Pendidikan }\end{array}$ & nonbasis & $\begin{array}{l}\text { non } \\
\text { prospektif }\end{array}$ & $\begin{array}{l}\text { nonbasis, } \\
\text { non } \\
\text { prospektif }\end{array}$ \\
\hline 16 & $\begin{array}{l}\text { Jasa } \\
\text { Kesehatan } \\
\text { dan Kegiatan } \\
\text { Social }\end{array}$ & nonbasis & $\begin{array}{l}\text { non } \\
\text { prospektif }\end{array}$ & $\begin{array}{l}\text { nonbasis, } \\
\text { non } \\
\text { prospektif }\end{array}$ \\
\hline 17 & Jasa Lainnya & nonbasis & $\begin{array}{l}\text { non } \\
\text { prospektif }\end{array}$ & $\begin{array}{l}\text { nonbasis, } \\
\text { non } \\
\text { prospektif }\end{array}$ \\
\hline
\end{tabular}

Kuadran I pada tipologi Klassen menunjukkan sektor yang menjadi basis dan memiliki prospek untuk dikembangkan ke depan. Sektor Pertanian, Kehutanan, dan Perikanan serta Sektor Konstruksi ada pada kuadran ini. Sesuai dengan karakteristik Kabupaten Lampung Tengah yang berciri agraris, maka tidak aneh jika sektor pertanian yang menjadi basis ekonomi. Sektor konstruksi dapat menjadi salah satu sektor yang prospektif mengingat pertumbuhan sektor ini mulai meningkat. Salah satu kemungkinan besar yang menjadi pendorong hal ini adalah adanya pembangunan jalan tol lintas Sumatra yang mulai membuka akses sekaligus membuka lapangan kerja pada saat pembangunan jalan tol tersebut.

Sektor konstruksi memiliki prospek yang cukup baik karena dengan mulai terbukanya akses ke Kabupaten Lampung Tengah akan menarik para investor terutama dalam pengembangan perumahan dan real estate. Selain membuka lapangan kerja dan mendorong ekonomi, pertumbuhan sektor ini akan meningkatkan aliran investasi masuk ke Kabupaten Lampung Tengah.

Sektor ekonomi yang berada pada kuadran II juga dapat dikembangkan oleh pembuat kebijakan. Meskipun bukan menjadi basis ekonomi Kabupaten Lampung Tengah, namun sektor-sektor seperti Pertambangan dan Penggalian, Transportasi dan Pergudangan, Informasi dan Komunikasi, serta Industri Jasa seperti Jasa Keuangan dan Asuransi serta Jasa Perusahaan juga layak untuk dikembangkan. Keterbukaan akses sebagai dampak pembangunan infrastruktur antardaerah cukup signifikan dalam mendukung perkembangan sektor-sektor yang berada pada Kuadran II.

\begin{tabular}{|c|c|}
\hline \begin{tabular}{l}
\multicolumn{1}{c}{ Kuadran I } \\
Sektor Basis Prospektif \\
- Pertanian, Kehutanan, \\
dan Perikanan \\
- Konstruksi
\end{tabular} & $\begin{array}{c}\text { Kuadran III } \\
\text { Sektor Basis Tidak } \\
\text { Prospektif } \\
\text { - Industri Pengolahan }\end{array}$ \\
\hline $\begin{array}{l}\text { Kuadran II } \\
\text { Sektor Nonbasis Prospektif } \\
\text { - Pertambangan dan } \\
\text { Penggalian } \\
\text { - Transportasi dan } \\
\text { Pergudangan } \\
\text { - Informasi dan } \\
\text { Komunikasi } \\
\text { - Jasa Keuangan dan } \\
\text { Asuransi } \\
\text { - Jasa Perusahaan }\end{array}$ & \begin{tabular}{l} 
Kuadran IV \\
Sektor Nonbasis Tidak \\
\multicolumn{1}{c}{ Prospektif } \\
- Electricity dan Gas \\
- Pengadaan Air, \\
Pengelolaan Sampah \\
dan Lainnya \\
- Perdagangan Besar dan \\
Reparasi Kendaraan \\
- Penyediaan Akomodasi \\
dan Makan Minum \\
- Real Estate \\
- Administrasi \\
Pemerintahan, \\
Pertahanan dan Jaminan \\
- Sosial Wajib \\
- Jasa Pendidikan \\
- Jasa Kesehatan dan \\
Kegiatan Sosial \\
- Jasa lainnya
\end{tabular} \\
\hline
\end{tabular}

Gambar 4. Klasifikasi Sektor Ekonomi Kabupaten Lampung Tengah 2016-2020 berdasarkan Tipologi Klassen

\section{Analisis Shift-share Kabupaten Lampung Tengah}

Shift-share merupakan suatu metode alternatif untuk mengukur laju pertumbuhan dan daya saing suatu wilayah. Melalui metode ini, suatu sektor ekonomi dapat diukur cepat atau lambatnya tingkat pertumbuhan suatu wilayah, termasuk sektor yang menjadi penyumbang daya saing suatu wilayah terhadap wilayah lain. Analisis Shift-share Kabupaten Lampung Tengah dilakukan dengan menghitung PN atau pertumbuhan ekonomi provinsi Lampung sebagai faktor yang memengaruhi pertumbuhan ekonomi Kabupaten Lampung Tengah dari sisi eksternal. Pertumbuhan proporsional (PP) 
digunakan untuk mengukur laju pertumbuhan di Kabupaten Lampung Tengah, sedangkan pertumbuhan pangsa wilayah (PPW) digunakan untuk melihat tingkat daya saing Kabupaten Lampung Tengah terhadap wilayah lain.

Dari data tabel pada Lampiran 5 dapat dilihat bahwa laju pertumbuhan ekonomi Provinsi Lampung mampu memberikan pengaruh sebesar kurang dari 5,96 milyar rupiah atau sekitar 93 persen terhadap peningkatan PDRB Kabupaten Lampung Tengah. Sektor Pertanian, Kehutanan dan Perikanan memberikan kontribusi tertinggi dengan nilai PN sebesar 2,13 milyar rupiah.

Kecepatan pertumbuhan ekonomi Kabupaten Lampung Tengah melalui PP ternyata bernilai negatif atau lebih kecil dari nol $(<0)$ sehingga dapat disimpulkan bahwa laju pertumbuhan di Kabupaten Lampung Tengah secara agregat mengalami perlambatan. Hal yang menarik adalah bahwa meskipun Sektor Pertanian, Kehutanan dan Perikanan berperan sebagai penyumbang nilai pertumbuhan tertinggi namun juga memberikan kontribusi signifikan terhadap perlambatan ekonomi di Kabupaten Lampung Tengah. Sektor ekonomi yang mengalami pertumbuhan secara cepat adalah Sektor Konstruksi, Sektor Industri Pengolahan, dan Sektor Informasi dan Komunikasi.

Komponen terakhir dari analisis Shiftshare Kabupaten Lampung Tengah adalah PPW. Secara agregat daya saing Kabupaten Lampung Tengah mengalami peningkatan yang ditunjukkan dengan PDRB yang meningkat sebesar 0,69 milyar rupiah. Daya saing tertinggi Kabupaten Lampung Tengah kembali dimiliki oleh Sektor Pertanian, Kehutanan, dan Perikanan diikuti oleh Sektor Industri Pengolahan.

Pergeseran bersih (PB) atau Net Shift Kabupaten Lampung Tengah diperoleh dengan menjumlahkan nilai PP dengan nilai PPW. Berdasarkan hasil penghitungan, nilai PB Kabupaten Lampung Tengah yang bernilai negatif meliputi tiga sektor yaitu
Sektor Pertanian, Kehutanan, dan Perikanan, Sektor Perdagangan Besar dan Reparasi Kendaraan, serta Sektor Real Estat. Hal ini berarti pertumbuhan sektorsektor tersebut bersifat lamban.

\begin{tabular}{|c|c|}
\hline $\begin{array}{l}\text { Kuadran I } \\
\text { Sektor dengan } \\
\text { Pertumbuhan Cepat dan } \\
\text { Berdaya Saing } \\
\text { - Transportasi dan } \\
\text { Pergudangan } \\
\text { - Informasi dan } \\
\text { Komunikasi }\end{array}$ & \begin{tabular}{l}
\multicolumn{1}{c}{ Kuadran III } \\
Sektor dengan \\
Pertumbuhan Cepat dan \\
Tidak Berdaya Saing \\
\\
- Industri Pengolahan \\
- Electricity dan Gas \\
- Pengadaan Air, \\
Pengelolaan Sampah dan \\
Lainnya \\
- Konstruksi \\
- Penyediaan Akomodasi \\
dan Makan Minum \\
- Administrasi \\
Pemerintahan, \\
Pertahanan dan Jaminan \\
Sosial Wajib \\
- Jasa Pendidikan \\
- Jasa Kesehatan dan \\
Kegiatan Sosial \\
- Jasa lainnya
\end{tabular} \\
\hline $\mathrm{PP}(+), \mathrm{PPW}(+)$ & PP (+), PPW (-) \\
\hline \begin{tabular}{l}
\multicolumn{1}{c}{ Kuadran II } \\
Sektor dengan \\
Pertumbuhan Lambat \\
dan Berdaya Saing \\
\\
- Pertanian, Kehutanan, \\
dan Perikanan \\
- Pertambangan dan \\
Penggalian \\
- Jasa Keuangan dan \\
Asuransi
\end{tabular} & \begin{tabular}{l}
\multicolumn{1}{c}{ Kuadran IV } \\
Sektor dengan \\
Pertumbuhan Lambat dan \\
Tidak Berdaya Saing \\
- Perdagangan Besar dan \\
Reparasi Kendaraan \\
- Real Estate \\
- Jasa Perusahaan
\end{tabular} \\
\hline PP (-), PPW (+) & PP (-), PPW (-) \\
\hline
\end{tabular}

Gambar 5. Kuadran Shift-share Sektor Ekonomi Kabupaten Lampung Tengah 2016-2020

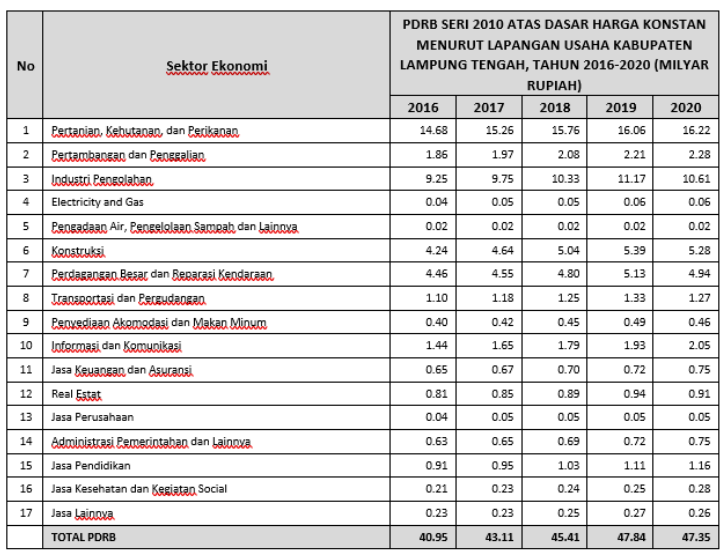

Gambar 6. Perkembangan PDRB Kabupaten Lampung Tengah 2016-2020 


\begin{tabular}{|c|c|c|c|c|c|c|}
\hline \multirow[t]{2}{*}{ No } & \multirow[t]{2}{*}{ Sektor Ekonomi } & \multicolumn{5}{|c|}{$\begin{array}{l}\text { PDRB SERI } 2010 \text { ATAS DASAR HARGA KONSTAN } \\
\text { MENURUT LAPANGAN USAHA PROVINSI LAMPUNG, } \\
\text { TAHUN 2016-2020 (MIIYAR RUPIAH) }\end{array}$} \\
\hline & & 2016 & 2017 & 2018 & 2019 & 2020 \\
\hline 1 & 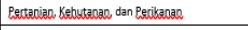 & $65,730.54$ & $66,297,14$ & $66,941.02$ & $67,839.72$ & $68,285.20$ \\
\hline 2 & 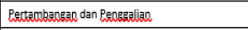 & $12,606.33$ & 13,41234 & $13,684.54$ & $14,053.72$ & $13,561.77$ \\
\hline 3 & Lodustrilenoglabana & $37,326.31$ & $39,633,96$ & $43,218.14$ & $46,778.31$ & $44,324.68$ \\
\hline 4 & Elestricty and Gas & 269.49 & 373.06 & 397.45 & 434.62 & 432.00 \\
\hline 5 & 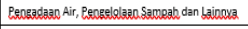 & 207.84 & 222.70 & 230.69 & 242.88 & 255.16 \\
\hline 6 & Keonstryksi & $18,963.10$ & $22,044.12$ & $22,798.26$ & $24,169.12$ & $23,673.65$ \\
\hline 7 & 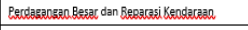 & $24,819.05$ & $26,435.15$ & $28,251.04$ & $30,285.06$ & $28,273.12$ \\
\hline 8 & Irasspettasid dan Rencerdendesean & $10,566.31$ & $11,263.64$ & $11,934.70$ & $12,998.54$ & $12,174,48$ \\
\hline 9 & 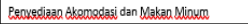 & $2,813.11$ & 3,038.88 & $3,357.79$ & $3,663.40$ & $3,479.86$ \\
\hline 10 & 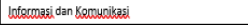 & $9,300.23$ & $10,299.09$ & $11,137.43$ & $12,024,21$ & $12,988.46$ \\
\hline 11 & 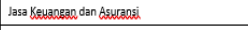 & $4,476.30$ & $4,677.88$ & $4,784.08$ & $4,920.37$ & $5,105.27$ \\
\hline 12 & \begin{tabular}{|l|l|l|l} 
Real Estat \\
\end{tabular} & $6,424.31$ & $6,807.09$ & $7,045.41$ & $7,459.61$ & $7,330.19$ \\
\hline 13 & Jasa Perusahaan & 297.46 & 314.92 & 321.80 & 334.57 & 329.78 \\
\hline 14 & 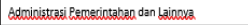 & $6,456.92$ & $6,727,75$ & $7,220.89$ & $7,461.55$ & $7,829.86$ \\
\hline 15 & \begin{tabular}{|l|l|} 
Jasa Pendidikan \\
\end{tabular} & $5,723.37$ & $6,012.17$ & $6,558.42$ & $7,104.74$ & $7,396.83$ \\
\hline 16 & 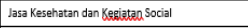 & $2,019.68$ & $2,115.93$ & $2,249.07$ & $2,402.19$ & $2,664.65$ \\
\hline 17 & Jasa bajocka & $1,793.40$ & $1,953.28$ & $2,135.26$ & $2,307.76$ & $2,201.99$ \\
\hline & TOTAL P DRB & $209,793.73$ & 220,626.10 & \begin{tabular}{|l|l|} 
& $232,165.99$
\end{tabular} & 244,380.37 & $240,30.86$ \\
\hline
\end{tabular}

Gambar 7. Perkembangan PDRB Provinsi Lampung 2016-2020

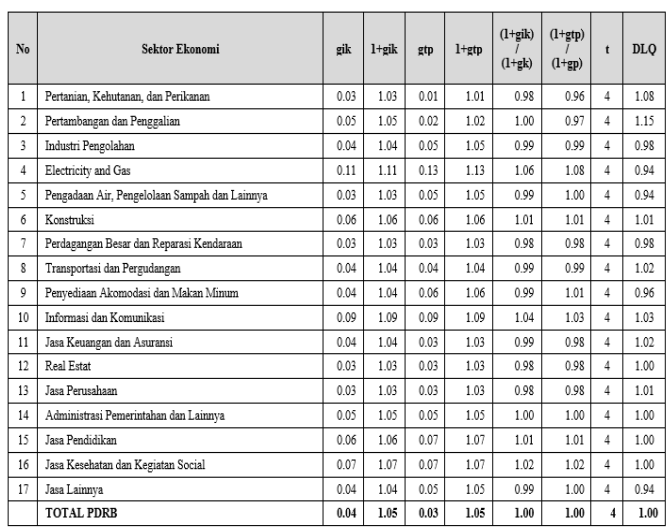

Gambar 8. Hasil Perhitungan Rata-Rata LQ Kabupaten Lampung Tengah dan Provinsi Lampung Tahun 2016-2020

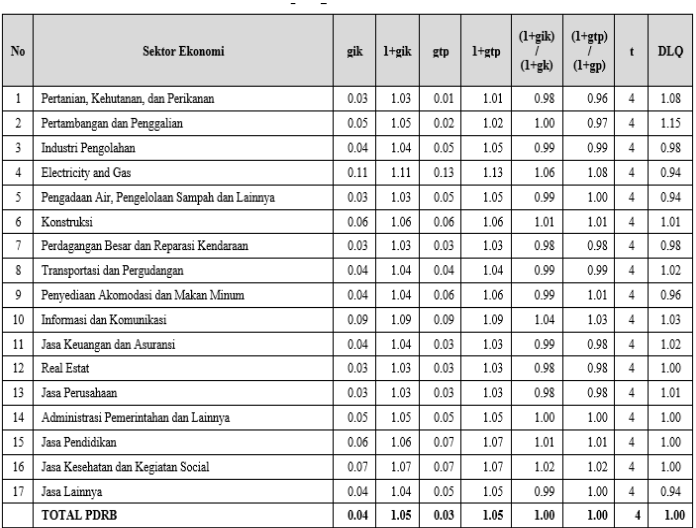

Gambar 9. Hasil Penghitungan DLQ Kabupaten Lampung Tengah dan Provinsi Lampung 20162020

\begin{tabular}{|c|c|c|c|c|c|c|c|c|c|}
\hline \multirow{2}{*}{$\mathrm{N}_{0}$} & \multirow{2}{*}{ Sektor Ekonomi } & \multicolumn{2}{|c|}{$\begin{array}{c}\begin{array}{c}\text { PNij }= \\
(\mathrm{Ra})^{+(}(\mathrm{Yij})\end{array} \\
\end{array}$} & \multicolumn{2}{|c|}{$\begin{array}{l}P P i j=(R i- \\
R_{0.0}^{ \pm}\left(Y_{i j}\right)\end{array}$} & \multicolumn{2}{|c|}{ 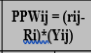 } & \multicolumn{2}{|c|}{$\begin{array}{c}\begin{array}{c}\text { PBij } \\
\text { (PWWij }\end{array} \\
\text { PPWij }\end{array}$} \\
\hline & & Milyar & $\%$ & Milyar & $\%$ & Milyar & $\%$ & Nilyar & $\%$ \\
\hline 1 & Pertanin, Kehutanan, dan Ferilanan & 2.13 & 14.54 & -1.56 & -1066 & 0.98 & 6.65 & .0 .59 & -4.01 \\
\hline 2 & \begin{tabular}{|l|} 
Pertambengan dan Pengggalin \\
\end{tabular} & 0.27 & 14.54 & -0.13 & -697 & 0.28 & 15.21 & 0.15 & 0.00 \\
\hline 3 & \begin{tabular}{|l|} 
Industrit Pengoldhar \\
\end{tabular} & 1.34 & 14.54 & 0.99 & 420 & .0 .37 & 4.02 & 0.02 & 0.18 \\
\hline 4 & Electicily and Gaz & 0.01 & 14.54 & 0.02 & 4576 & 0.00 & .731 & 0.02 & 38.45 \\
\hline 5 & 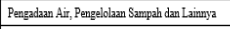 & 0.00 & 14.54 & 0.00 & 823 & 0.00 & 8.14 & 0.00 & 0.09 \\
\hline 6 & Konstrulki & 0.62 & 14.54 & 0.4 & 1030 & -0.02 & .0 .38 & 0.42 & 9.92 \\
\hline 7 & Perdaganzan Bear dan Reparasi Kendaran & 0.65 & 14.54 & -0.03 & -0.63 & .0 .14 & 3.16 & .0 .17 & -3.79 \\
\hline 8 & \begin{tabular}{|l|} 
Transpotasi dan Rergydangen \\
\end{tabular} & 0.16 & 14.54 & 0.01 & 0.68 & 0.01 & 0.69 & 0.02 & 1.37 \\
\hline 9 & Panyedian Alomomdaxi dan Nazkan Minum & 0.06 & 14.54 & 0.4 & 9.16 & -0.02 & .6 .32 & 0.01 & 2.84 \\
\hline 10 & Intomaxii dan Roumunkasi & 0.21 & 14.54 & 0.36 & 25.11 & 0.04 & 246 & 0.40 & 27.58 \\
\hline 11 & \begin{tabular}{|l} 
Jasa Reurangan dan.Asurnsi \\
\end{tabular} & 0.09 & 14.54 & 0.00 & -0.49 & 0.01 & 0.96 & 0.00 & 0.47 \\
\hline 12 & Real Estat & 0.12 & 14.54 & 0.00 & .044 & .0 .01 & .1 .44 & -0.02 & -1.88 \\
\hline 13 & Jas Persuhahan & 0.01 & 14.54 & 0.00 & \begin{tabular}{l|l}
.368 \\
\end{tabular} & 0.00 & .0 .50 & 0.00 & -4.17 \\
\hline 14 & 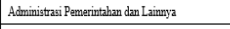 & 0.09 & 14.54 & 0.4 & 672 & -0.01 & .1 .84 & 0.03 & 4.88 \\
\hline 15 & Jasa Pennididzan & 0.13 & 14.54 & 0.13 & 1469 & -0.01 & .1 .48 & 0.12 & 13.22 \\
\hline 16 & 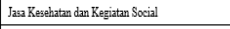 & 0.03 & 14.54 & 0.4 & 1739 & 0.00 & 2.06 & 0.03 & 15.33 \\
\hline 17 & \begin{tabular}{|l} 
J Jsa L a ainya \\
\end{tabular} & 0.03 & 14.54 & 0.02 & 824 & -0.02 & 8.36 & 0.00 & \begin{tabular}{|c|c|}
-0.13 \\
\end{tabular} \\
\hline & Total PDRB & 8.96 & & -0.25 & & 0.69 & & 0.44 & \\
\hline
\end{tabular}

Gambar 10. Analisis Shift-share Kabupaten Lampung Tengah Tahun 2016-2020

\section{KESIMPULAN}

Analisis penghitungan LQ dan DLQ Kabupaten Lampung Tengah menghasilkan kesimpulan bahwa hanya terdapat 3 sektor ekonomi yang berperan sebagai sektor basis atau unggulan dalam perekonomian Kabupaten Lampung Tengah yaitu Pertanian, Kehutanan, dan Perikanan, Industri Pengolahan, serta Konstruksi. Sebagai daerah yang bercirikan agraris, tidak mengherankan jika sektor Pertanian menjadi basis utama ekonomi Kabupaten Lampung Tengah. Akan tetapi, minimnya nilai pertumbuhan ekonomi dari sektor basis ini serta lambatnya laju sektor pertanian menunjukkan tingkat daya saing Kabupaten Lampung Tengah yang masih rendah. Keadaan ini perlu mendapat perhatian dari pemangku kebijakan untuk merumuskan strategi yang tepat bagi pengembangan ekonomi di wilayah Kabupaten Lampung Tengah.

Hasil analisis menunjukkan bahwa sektor ekonomi yang memiliki pertumbuhan cepat dan progresif dan berpotensi untuk meningkatkan daya saing daerah yaitu Transportasi dan Pergudangan serta Informasi dan Komunikasi. Kedua sektor ini juga termasuk sektor yang prospektif dari hasil analisis LQ meskipun berstatus sektor nonbasis. Dengan demikian kedua sektor ini potensial untuk dikembangkan sehingga dapat mendukung 
pertumbuhan ekonomi Kabupaten Lampung Tengah di masa mendatang.

Terbukanya akses transportasi melalui pembangunan jalan tol lintas sumatra kemungkinan besar menjadi salah satu faktor pertumbuhan sektor transportasi dan pergudangan. Untuk perkembangan di sektor Informasi dan Komunikasi masih perlu analisis lebih lanjut mengingat adanya pandemi Covid-19 yang secara tidak langsung meningkatkan pertumbuhan sektor informasi dan komunikasi. Hal ini terjadi karena pembatasan sosial dan sistem pendidikan yang dialihkan dari luar jaringan atau offline menjadi dalam jaringan (daring) atau online.

Identifikasi sektor basis ekonomi suatu wilayah tidak serta merta menunjukkan keunggulan tingkat perekonomian daerah tersebut. Metode ini juga mengandalkan data yang bersifat historis sehingga apabila terjadi perubahan kebijakan maupun kondisi perekonomian di masa depan, hal tersebut dapat merubah peta persebaran sektor basis ekonomi maupun nonbasis suatu daerah. Namun, pendekatan LQ, DLQ, dan Shift-share cukup memberikan informasi mengenai potensi dan keunggulan sektor ekonomi suatu daerah. Selain itu, keadaan ekonomi yang mengalami dampak penyebaran virus Covid-19 secara tidak langsung juga pasti berpengaruh dalam pergerakan ekonomi daerah.

\section{DAFTAR PUSTAKA}

Afif, F. Y., \& Ciptawaty, U. (2020). KEMANDIRIAN KEUANGAN DAERAH DAN PERTUMBUHAN EKONOMI KABUPATEN/KOTA LAMPUNG TAHUN ANGGARAN 2014-2018. E-Journal EKonomi Dan Bisnis Universitas Udayana, 9(7), 609-626.

Arcelus, F. J. (1984). An extension of shiftshare analysis. Growth and Change, 15(1), 3-8.

Arsyad, L. (1999). Pengantar Perencanaan dan Pembangunan Ekonomi Daerah. BPFE UGM.

Basuki, M., \& Mujiraharjo, F. N. (2017). Analisis Sektor Unggulan Kabupaten Sleman dengan Metode Shift Share dan Location Quotient. Jurnal Sains, Teknologi Dan Industri, 15(1), 52-60.

BPS. (2020). Berita Resmi Statistik Juli 2020.

https://www.bps.go.id/website/materi _ind/materiBrsInd20200715120937.pdf

BPS Lampung. (2021). Berita Resmi Statistik.

Chiang, S. hen. (2012). Shift-share analysis and international trade. Annals of Regional Science, 49(3), 571-588. https://doi.org/10.1007/S00168-0110465-1

Curtis, W. C. (1972). Shift-Share Analysis as a Technique in Rural Development Research. American Journal of Agricultural Economics, 54(2), 267270. https://doi.org/10.2307/1238712

Dinas Komunikasi Informasi Statistik dan Persandian Kab. Paser. (2019). Analisis Produk Domestik Regional Bruto Menurut Lapangan Usaha Kabupaten Paser Tahun 2019. Dinas Komunikasi Informasi Statistik dan Persandian Kab. Paser.

Isserman, A. M. (1977). The Location Quotient Approach to Estimating Regional Economic Impacts. Journal of the American Planning Association, 43(1), 33-41. https://doi.org/10.1080/01944367708 977758

Khusaini, M. (2015). A Shift-share Analysis on Regional Competitiveness - A Case of Banyuwangi District, East Java, Indonesia. Procedia - Social and Behavioral Sciences, 211, 738-744. https://doi.org/10.1016/J.SBSPRO.20 15.11.097 
Kurniati, N. (2020). Analisis Pertumbuhan Ekonomi dan Struktur Perekonomian Wilayah Kota Mataram. MEDIA BINA ILMIAH, 15(1), 3799-3806.

Nugroho, A. D. (2010). Komoditas Unggulan Tanaman Pangan di Pulau Jawa. Agro Ekonomi, 17(1), 67-72.

Oyewole, P. (2016). Regional Competition in the International Market for Services: A Shift-Share Analysis. Journal of Global Marketing, 29(1), 3-14.

https://doi.org/10.1080/08911762.201 5.1119918

Page, G. W., \& Patton, C. V. (1991). SHIFT-SHARE ANALYSIS. In Quick Answers to Quantitative Problems (pp. 99-103). Academic Press. https://doi.org/10.1016/B9780-12-543570-3.50013-4

R. Jumiyanti, K. (2018). Analisis Location Quotient dalam Penentuan Sektor Basis dan Non Basis di Kabupaten Gorontalo. Gorontalo Development Review, 1(1), 29-43. https://doi.org/10.32662/golder.v1i1.1 12

Ridwan. (2016). Pembangunan Ekonomi Regional.

Schaffer, W. a. (2010). Regional models of income determination: simple economic-base theory. In Economic Base Theory (p. 42).

Sihombing, F. N. (2018). Identifikasi Pangan Unggulan Di Kota Medan: Location Quotient Dan Dynamic Location Quotient. Jurnal Pembangunan Perkotaan, 6(2), 91-94.

Soepono, P. (2001). Teori Pertumbuhan Berbasis Ekonomi: Posisi dan Sumbangannya Bagi Perbendaharaan Alat-Alat Analisis Regional. Ekonomi Dan Bisnis Indonesia, 16(1), 41-53.
Sofi, I. (2020). Analisis Sektor Unggulan Kabupaten Penajam Paser Utara Tahun 2015-2019. Jurnal Anggaran Dan Keuangan Negara Indonesia (Akurasi), 2(2), 112-130.

Sugiyono. (2011). Metode Penelitian Kuantitatif, Kualitatif, dan $R \& D$. Alfabeta.

Sukirno, S. (2000). Pengantar Teori Makroekonomi. PT. Raja Grafindo Persada.

Erdi Suroso, Wisnu Satyajaya (2016). Kajian Keputusan Komoditas Unggulan Pengembangan Agroindustri Perdesaan di Kabupaten Tulang Bawang. Jurnal Inovasi Pembangunan, Volume 04 No. 1 2236).

Ridwan Saifuddin (2020), Pemanfaatan Teknologi Informasi Dalam Peningkatan Pendapatan Asli Daerah . Jurnal Imovasi Pembangunan, Volume 08 No. 2 (183).

Satyajaya, W., Suroso, E., Alrasyid, H., \& Utomo, T. P. (2016). Kajian Penentuan Komoditas Unggulan dalam Pengembangan Teknologi Agroindustri Rakyat di Kabupaten Tulang Bawang. Jurnal Inovasi Pembangunan Volume 04 No. 1, 2236.

Christina, M., \& Pratiwi, Y. (2017). Analisis Sektor Unggulan dan Transformasi Struktural di Provinsi Kalimantan Tengah 2010 - 2016. Jurnal Inovasi Pembangunan Volume 5 No. 3, 184-205 